\title{
Constituição e Mobilização de Saberes Docentes: Perscrutando Práticas de Professores de Biologia no Ensino Médio
}

\section{Constitution and Mobilization of Knowledge Teachers: Peering Practices of Biology Teacher in High School}

\author{
Renata Confortin

O presente estudo circunscreve-se no campo da epistemologia da prática e se justifica pela necessidade de apreender os processos de constituição profissional e de apropriação e mobilização de saberes dos professores, com vistas a analisar as práticas que se desenrolam no cotidiano das escolas e das salas de aula. No esforço de identificar as especificidades que caracterizam a prática de dois professores de Biologia no ensino médio, investigou-se como se constituem e mobilizam seus saberes docentes na confluência das experiências familiares, escolares, formativas e sociais. O caminho metodológico foi percorrido a partir da triangulação entre três procedimentos: a história de vida, a entrevista semiestruturada e a observação de aulas. Depreende-se, dos percursos desses professores, a influência de seus educadores ao longo da escolarização básica e superior. A experiência também ocupa lugar central na constituição de seus saberes enquanto professores de Biologia. No que concerne aos modos de mobilização de saberes, compreende-se que os percursos são muito particularizados em função, dentre outros fatores que apareceram menos evidentes, da fase em que se encontram na carreira. A professora experiente parece mobilizar saberes mais especificamente na gestão da classe, ao passo que o professor novato o faz na gestão da matéria. Ainda, evidencia-se que a prática destacada dos dois professores investigados é marcada pelo gosto de exercer a docência, por um profundo carinho pelos alunos, pela importância que atribuem ao ser professor, pela responsabilidade com que assumem a condução da sala de aula.

Palavras-chave: Professor Biologia; Ensino Médio; Formação de Professores; Saberes docentes.

The present surveying work is circumscribed on the epistemology field of teaching practice and it is academically justified by the necessity of learning the managing procedures on the professional formation and on the seizure and deployment of teachers' knowledge, looking forward to examine the customary performances daily developed at schools and classrooms. Under the effort to identify the particularities that 
characterizes the methodology processes of two teachers of Biology in High School, it has been researched on which is and how they assemble their scholar knowledge on the convergence of family, scholar, educational and social know-hows. The methodological path has been crisscrossed considering the triangulation on three procedures: life history, a semi-structured interview and classes' surveillance. It has been inferred, considering the teachers' experience, the inspiration that scholars had all along their education, from School to Graduation. Experience has also been a foremost component of their knowledge as Biology teachers. Regarding the behavior they summon in their scholar's experience, it has been understood that their know-how are pretty individualized, due to the fact - among others, less evident, the career's stage they are performing nowadays. The more experienced teacher looks like deploying her knowledge more specifically in class managing, whilst the less one seems to organize her know-how more particularly on the subject of study, Biology. The present survey also remarks, that the practice of the teaching issues related to both teachers, is impressed by their motivation for teaching, as well as a profound endearment for their students, the importance given to the fact of being teachers and the shown responsibility leading their classes.

Keywords: Biology Teacher; High School; Teacher's professional education; Teaching knowledge.

\section{Introdução: O Início dessa Caminhada}

Nossa experiência docente na licenciatura em Biologia e na área de supervisão de estágios curriculares de graduação em contextos escolares, tem suscitado interrogações sobre ações, relações e fenômenos que se dão no chão da escola, no fazer pedagógico cotidiano e que interferem na constituição e na práxis docente, como, por exemplo, por que são tão diferentes os professores em sua forma de ensinar e de viver a docência? Debruçamo-nos sobre o presente tema por acreditarmos que a atuação dos professores em sala de aula, diante do cenário atual de sociedades complexas e diversas, é critério chave para a qualificação dos processos de ensino e aprendizagem, que reflete diretamente na qualidade da educação.

É de Nóvoa (1995a) a afirmação de que não há receitas para a solução de problemas pedagógicos, uma vez que a sala de aula é altamente complexa e não é possível reduzila a poucas variáveis a manipular. Com base em tais pressupostos, sem desconsiderar nenhum outro viés implicado nessa questão e nem mesmo a complexidade do problema, mas no esforço de delimitá-lo, dedicamo-nos a investigar a atuação dos professores, procurando compreender a natureza e a origem das diferenças entre eles em sua prática pedagógica, voltando nosso olhar e nossa escuta ao entendimento dos saberes docentes.

De acordo com Tardif (2012), saber docente pode ser definido como "saber plural, formado pelo amálgama, mais ou menos coerente, de saberes oriundos da formação profissional e de saberes disciplinares, curriculares e experienciais" (p.36). Tais saberes são diversos em sua tipologia e natureza. Podem ser técnicas, conhecimento 
científico, saberes eruditos, ações, crenças, experiências, valores (Tardif, 2012); podem ser saberes mais ou menos subjetivos, enfim, é grande a gama de saberes que constitui ou pode constituir o professor. Para Gauthier, Martineau, Malo e Simard (1998), os saberes docentes são os saberes disciplinares, curriculares, das ciências da educação, da tradição escolar, da experiência e da ação pedagógica. Para Pimenta (2012), são os saberes da experiência, do conhecimento e pedagógicos. Não há um consenso de quais são os saberes necessários a um professor, mas tem-se uma direção, eles são importantes indicadores da qualidade da prática docente. Nesta vertente, o ensino pode ser concebido, de acordo com Gauthier et al. (1998) como "a mobilização de vários saberes que formam uma espécie de reservatório no qual o professor se abastece para responder a exigências específicas de sua situação concreta de ensino” (p.28).

Nóvoa (2007), por este viés, questiona "Por que é que fazemos o que fazemos em sala de aula?" (p.16). Essa questão do autor nos direciona para a compreensão das diferenças na atuação em sala de aula em comparação a outros professores. Assim, para precisar o foco desta investigação, fizemos novo recorte na problemática e buscamos identificar a prática pedagógica específica de professores de Biologia atuando no ensino médio. A importância do professor de Biologia nos contextos escolares é entendida quando se analisa a relevância dos conhecimentos biológicos do homem e do mundo nos tempos atuais, para a manutenção e sobrevivência do planeta Terra, e do ser humano com saúde e qualidade de vida, convivendo de forma sustentável neste e com este planeta.

É frequente, nesse cenário, encontrarmos professores de Biologia que transcendem o fazer docente pautado no discurso verbalista que caracteriza a lógica vigente na maioria dos contextos educacionais hoje. São professores que extrapolam os limites da racionalidade técnica, operando a partir da reflexão-ação-reflexão, conforme conceito cunhado por Schön (2000). Tal distinção é notada pelos alunos, pelos pares, pais, gestão, supervisores de estágio, dentre outros sujeitos ligados ao contexto educativo. No entanto, também são notadas dificuldades e fragilidades na atuação do professor de Biologia. Essa percepção se dá a partir das falas dos alunos, na convivência com os professores da área, em trocas informais nas salas de professores ou nos momentos de formação. Percebe-se que boa parte dos professores atua no ensino de Biologia de modo distanciado da vida e da realidade do aluno. Parece paradoxal que, justamente tratando de assuntos que são da seara da Ciência que estuda a vida, se tangencie o objeto principal de estudo.

Têm-se, nesta mesma direção, professores fazendo uso somente do livro ou outro material didático como agente de mediação do ensino e da aprendizagem, ou fazendo uso precário destes, sem explorar todo o conteúdo ou as possibilidades que oferecem. Ou, ainda, apegando-se demasiadamente aos currículos engessados e inflados que definem conteúdos da disciplina, os quais, ao invés de abrir horizontes para o conhecimento, tolhem-no. Encontram-se, ainda, professores com relativa dificuldade em proceder à transposição didática do saber biológico, de modo a torná-lo um saber escolar socialmente relevante e atualizado, face à velocidade com que novos conhecimentos são produzidos na área. Outra situação bastante evidente é a subutilização ou a não-utilização 
dos laboratórios de ciências das escolas ou os espaços externos a estas para as chamadas aulas práticas - neste estudo compreendidas a partir do conceito de experimentação didática, cerne do saber biológico -, privilegiando-se métodos expositivos e de repetição de exercícios e atividades teóricas. Essas constatações empíricas são ratificadas pelos estudos de Marandino, Selles e Ferreira (2009), Ferreira, Guimarães e Souza (2011) e Martins e Leite (2013), que também apontam diversos aspectos lacunares na formação inicial dos professores de Biologia. Tais autores e obras destacam-se, ainda, na sucinta produção acadêmica sobre os saberes docentes específicos dos professores de Biologia.

Assim, diante dos argumentos expostos de que existe uma problemática na ação do ensino de Biologia, justifica-se a realização deste estudo, que se dá na busca do entendimento de quais saberes estes professores utilizam para diferenciarem-se dos demais e qualificarem sua prática; como mobilizam esses saberes docentes para emergirem entre tantos professores como aqueles que desenvolvem práticas qualificadas em sua atividade docente no campo da Biologia. Nessa direção, buscamos investigar como se constituem os saberes dos professores de Biologia e como são mobilizados em seu fazer pedagógico para ensinar esse componente curricular.

No esforço de ouvir o que professores de Biologia têm a dizer sobre a sua constituição enquanto docentes, situamos o estudo no campo da epistemologia da prática e dos saberes docentes. Nesse direcionamento, a pesquisa caracteriza-se como qualitativa, desenvolvida em três etapas: exploratória, de campo e de tratamento de dados empíricos e documentais, utilizando-se da orientação metodológica proposta por Minayo (2010).

$\mathrm{Na}$ fase exploratória deste estudo, foram produzidos, primeiramente, a revisão de literatura e o referencial teórico para dar sustentação às fases seguintes da pesquisa. No trabalho de campo, realizado no ano de 2014, buscou-se identificar professores de Biologia que tivessem sua prática marcada pela transcendência aos aspectos lacunares de atuação pedagógica. Ou seja, aquele professor que transcende na sua prática, conforme Tardif (2012),

[...] deve conhecer sua matéria, sua disciplina e seu programa além de possuir certos, nem por isso menores, conhecimentos relativos às ciências da educação e à pedagogia $\mathrm{e}$ desenvolver um saber prático baseado em sua experiência cotidiana com os alunos. (p.39)

Acredita-se, baseando-se nas pesquisas conduzidas por autores que investigam o campo da docência em Biologia, tais como Marandino, Selles e Ferreira (2009), Ferreira, Guimarães e Souza (2011) e Martins e Leite (2013), que o professor que se destaca nesta área de atuação é aquele que, não obstante as lacunas apresentadas em seu processo de formação inicial e no contexto escolar, consegue conduzir a aula buscando a superação da racionalidade técnica e pautando-se no paradigma da aprendizagem.

Desse modo, para compor os nomes desses professores de Biologia em atuação no ensino médio de escolas de fácil acesso às pesquisadoras, buscou-se pela indicação de quatro professores que atuam ou atuaram na disciplina de Estágio Supervisionado II do Curso de Licenciatura em Ciências Biológicas de uma Instituição de Ensino Superior. 
Isso, por serem profissionais que estão diretamente vinculados ao contexto da pesquisa, por atuarem tanto no processo de formação inicial de professores de Biologia, quanto por conviverem em escolas de ensino médio, nos momentos de supervisão de estágio, em contato com gestores e demais professores da área, titulares dos professores-estagiários.

Dentro dos critérios definidos destacaram-se, assim, dois professores. Nomeadamente, Professora Simone ${ }^{1}$, gênero feminino, nascida no ano de 1964, com a educação básica realizada em escola pública, concluiu a graduação em Ciências Biológicas, na Universidade de Passo Fundo (UPF/RS), no ano de 1984, tornando-se especialista em Biologia no ano 2000. Sua formação continuada se dá pela realização de jornadas, seminários e outros eventos que abordam conhecimentos gerais, em especial os relacionados às questões ambientais. Com 25 anos de atuação em sala de aula, à época da pesquisa (2014) ministrava as disciplinas de Ciências e Biologia em escolas de ensino fundamental e médio, pública e privada, apesar da aposentadoria. O Professor Lucas, por sua vez, do gênero masculino, nasceu no ano de 1989, fez sua formação básica em escola pública, concluiu o curso de graduação - Ciências Biológicas - na UPF, em 2010, e a especialização em Supervisão Escolar no ano de 2013. Sua formação continuada se dá pela reflexão do que ocorre em sala de aula, além dos momentos de formação oferecidos pelas escolas em que atua. Com três anos de experiência em docência, ao tempo do estudo leciona Biologia em turmas de $1^{\circ}$ e $2^{\circ}$ anos do ensino médio, em escola pública, em período integral e com dedicação exclusiva.

A partir da definição dos sujeitos, a produção de dados primários se deu pela triangulação de três procedimentos: história de vidas, entrevista semiestruturada e observação de três aulas ${ }^{2}$ de cada professor. As histórias de vidas foram produzidas em um momento de encontro particular e individualizado entre o sujeito de pesquisa e a pesquisadora, por aproximadamente 60 minutos, quando empreendeu-se escuta atenta da narrativa oral da Professora Simone e do Professor Lucas, que foi gravada em áudio para posterior transcrição. O relato se deu no sentido de os sujeitos de pesquisa discorrerem sobre temas essenciais de seu percurso de vida pessoal e profissional, tais como: aspectos de sua vida escolar inicial, média e superior, família e comunidade (instituições de que participa); motivos da escolha da profissão; aspectos de sua vida pessoal que possam ter influenciado nesta escolha e na sua atuação como professor; aspectos de sua formação inicial (graduação) e continuada; aspectos positivos e negativos na sua ação docente, mencionando seus pares (colegas professores), alunos, pais e gestão, dentre outros enfoques que, no decorrer dos relatos, surgiram e foram da vontade própria da Professora Simone e do Professor Lucas abordar.

Em um momento posterior, durante aproximadamente 45 minutos, desenvolveu-

1 Os nomes dos professores aqui adotados são fictícios, de modo a garantir o sigilo sobre sua identidade.

2 Utiliza-se ao longo do texto as denominações: HVPS e HVPL para designar os dados coletados dos professores Simone e Lucas, respectivamente através da história de vida (A sigla HVPS significa História de Vida da Professora Simone e HVPL refere-se ao Professor Lucas); ENTPS e ENTPL para referir-se aos dados coletados dos professores Simone e Lucas, respectivamente, através da entrevista; e, por fim OA1PS, OA2PS, OA3PS e OA1PL, OA2PL, OA3PL para pontuar a primeira, segunda e terceira observação de aulas ministradas respectivamente pela professora Simone e pelo Professor Lucas. 
se uma entrevista semiestruturada com cada sujeito a partir de questões pré-formuladas, com base em Tardif (2012), de modo a complementar as histórias de vida, entender como constituíram seus percursos para serem os professores de Biologia que hoje são, conhecer sua visão sobre o que é ser professor e o que é ser professor de Biologia, dentre outras. Privilegiou-se a busca de dados como titulação, experiência profissional, tempo de atuação na docência em Biologia, formação pedagógica e técnica para ministrar aulas de Biologia, perfil considerado desejado para o professor de Biologia, características lacunares e potenciais no ensino da Biologia.

As observações foram realizadas num terceiro momento, e consistiram na presença atenta da pesquisadora em sala de aula, de posse de um protocolo de observação, fazendo registros em áudio e em diário de campo sobre questões diversas do período escolar. Isso, para melhor compreender a maneira de ensinar desses professores, bem como para dar efetividade ao projeto de atuar dentro da epistemologia da prática, campo metodológico que ampara esta pesquisa. A observação de aulas, conforme AlvesMazzotti e Gewandsznadjer (1998), é extremamente valorizada pela pesquisa qualitativa, com a vantagem de ser independente do nível de conhecimento ou da capacidade verbal dos sujeitos.

De posse dos dados produzidos em campo por essa triangulação, a subsequente etapa da pesquisa consistiu na análise e tratamento do material empírico e documental, utilizando-se do método da análise de conteúdo proposto por Bardin (2011). A leitura flutuante dos materiais fez emergir duas unidades principais de análise, categorizadas como unidades de contexto, quais sejam: 1) a constituição dos saberes dos professores de Biologia; e, 2) a mobilização dos saberes dos professores de Biologia. A partir de então, configuraram-se quatro unidades de registro para cada unidade de contexto. São elas: 1a) influência da família/infância/adolescência/grupos sociais; 1b) influência da formação oficial (primária, secundária, superior/graduação); 1c) influência dos pares em situações profissionais; 1d) influência das práticas de extensão/formação continuada; e, 2 a) a experiência colocada em prática; 2 b) a gestão da classe; $2 c$ ) a gestão da matéria; e, finalmente, $2 \mathrm{~d}$ ) a opção, o gosto e a realização profissional na docência, como expõe-se na sequência.

\section{A Constituição dos Saberes dos Professores de Biologia}

Formar-se supõe troca, experiência, interações sociais, aprendizagens, um sem fim de relações. Ter acesso ao modo como cada pessoa se forma é ter em conta a singularidade da sua história e, sobretudo, o modo próprio como age, reage e interage em seus contextos. Assim, ocupa-se, aqui, de identificar a contribuição das vivências da infância, da adolescência, e na família, bem como a ligação da formação inicial e continuada e de atividades diversas de extensão, ou seja, fora dos contextos profissionais, na constituição dos saberes dos sujeitos desta pesquisa, como se detalha a seguir.

Das vivências da infância, da adolescência e da influência da família/grupos sociais, a Professora Simone não faz relatos que remetam a pensar sobre as marcas desta 
etapa de vida em sua opção ou formação profissional, apenas rememora alguns conflitos e poucas lembranças, dentre estas de momentos na escola. No entanto, ao analisar o depoimento do Professor Lucas são nítidas as marcas da infância tanto em sua escolha profissional como em sua constituição enquanto professor, e especificamente, como professor de Biologia.

Eu sempre gostei de estudar. Desde o início da infância, tinha umas primas que moravam perto de casa: elas acabavam brincando de dar aula: todo professor começa assim. Então surgiu essa vontade de ser professor. (HVPL)

A adolescência apareceu com diferentes vieses para os sujeitos da pesquisa na compreensão de como se tornaram os professores destacados que hoje são. Para o Professor Lucas, apesar de ter mencionado não se lembrar de fatos que o tenham marcado, foi um período que consolidou a decisão, principiada na infância, de ser professor. $\mathrm{O}$ período da adolescência pontua para os sujeitos de pesquisa recordações da escola e alguns conflitos que até hoje povoam as suas lembranças.

Colocando-se em foco a família para a compreensão da constituição dos sujeitos de pesquisa enquanto professores de Biologia, embora não decisiva, esta foi considerada fundamental no sentido de apoio à formação integral dos sujeitos. Percebe-se que os pais, de ambos, tiveram seus estudos concentrados apenas na iniciação escolar, ou seja, cursaram as séries iniciais do ensino fundamental. Isso, no entanto, não parece ter restringido a opção dos filhos por estudarem e avançarem em seus processos de formação. O Professor Lucas reconhece a importância da família para a sua formação, mas afirma que, para a escolha da profissão sempre foi "livre", ou seja, não houve cobranças por parte dos pais para a decisão de ser professor. Percebe-se, assim, que a infância, a adolescência, a família e os contextos de interação social influenciam os sujeitos de pesquisa em sua constituição como professores, no entanto, de modos diferentes, salientando os percursos únicos que percorremos para nos formarmos os professores que hoje somos.

No que concerne às vivências da formação primária, secundária e superior/ graduação, existe uma permanência de fundo, que ratifica a vontade de ser professor já declarada quando se tratou do período dainfância. O excerto a seguir evidencia a influência da formação primária na constituição do Professor Lucas e seu encaminhamento para a docência em Biologia, quando destaca elementos do conhecimento biológico, como a célula.

$\mathrm{Na} 4^{a}$ série nós aprendemos a célula. [...] Acho que foi a partir desse momento que eu comecei a me encaminhar para a questão de ser professor [...] célula é uma coisa que eu gosto de dar em aula - e são as coisas que agora pensando, eu mais gosto de dar aula. (HVPL)

Para a Professora Simone, as lembranças da escola (formação primária) vêm sempre relacionadas com fatores relacionais/sentimentais, como as colegas, as amizades, a convivência e atividades que possibilitavam essa troca. Do mesmo modo percebe-se 
que, constantemente, ao realizar seus relatos, essa professora faz comparações com a situação de sala de aula atualmente. Outro eixo que é possível identificar quando se analisa a influência da formação primária/secundária na constituição desses docentes de Biologia, é a forte presença de alguns professores, considerada na visão do Professor Lucas "fundamental" (ENTPL). Essa influência transita, ora por aspectos relacionais, ora por aspectos disciplinares. Sobre os primeiros, frisa-se o caso da professora que contou sobre sua vida para as alunas e o caso do professor que abordou positivamente o aluno de forma a fortalecer sua autoconfiança e autoestima.

Aqui da Escola a Luiza Laura, professora de Biologia. Adorava a professora de Biologia. Por que? Foi a única professora que parou (nem era por causa da Biologia), conversar com nós - loira, de olho azul, tipo Ana Hickmann. Ela disse que não entendia nada de mecânica, e o marido adorava, então ela foi estudar sobre mecânica para ter assunto com ele. Eu achei aquilo tão encantador. E fui fazer Biologia. (HVPS)

Vale repetir, do excerto recém apresentado, "Eu achei aquilo tão encantador. E fui fazer Biologia” (HVPS), para compreender a importância ímpar dos antigos professores na constituição dos saberes dos futuros ou então professores. Notada em função de que os aspectos que a Professora Simone ressalta como marcantes em sua professora, em especial a humanidade na atitude desta, parece ser o tipo de atitude que esta docente adota em sala de aula. Na mesma direção observa-se o relato do Professor Lucas:

Bom eu tenho várias recordações, de vários professores. Eu lembro de Geografia, na 6a/7a série, que sempre dizia que eu tenho que ter confiança em mim. Tem também uma outra professora que foi de Português, de leitura e produção de textos e tem uma disciplina que era parecida com Filosofia que ela deu que era "Interpretando e compreendendo a vida", era mais ou menos uma Filosofia, e várias coisas eu lembro nesse sentido de ser positivo, de pensar nas coisas focando a solução e não os problemas, de ter uma autoestima elevada. E é isso que eu procuro fazer. (HVPL)

No que concerne à lembrança dos professores em função de aspectos disciplinares, aparece pela nomeação de disciplinas específicas "professora de Português", a "professora de Interpretando e Compreendendo a Vida”, bem como de conteúdos disciplinares, como o estudo do "DNA", da "célula", "Genética" como se pode analisar na narrativa do Professor Lucas:

Eu lembro até hoje a primeira aula que nós tivemos de DNA, da adenina, o pareamento do DNA - coisas que me marcaram, eu lembro dos nomes, como eram feitos. Isso na faculdade eu lembro que depois tinha alguns colegas que não sabiam fazer isso, e eu sabia. Isso eu gosto de dar hoje na aula [...] (célula, biologia molecular, genética) - eu acho que agora que eu to me deparando com isso eu percebo que são as coisas que eu mais gosto (se referindo às lembranças que tem). No segundo ano eu tive Genética, eu tinha expectativa, em relação à Genética, os cruzamentos, como que acontecia. (HVPL)

Além da influência dos professores por meio de seu modo de ser/estar em sala de aula e dos ensinamentos perpassados, ainda tratando dos contextos de ensino secundário (ou médio), destacaram-se como fundamentais na narrativa do Professor 
Lucas as Feiras de Ciências/Biologia, entendidas como uma atividade de experimentação didática. Veja-se:

No terceiro ano também, teve a Feira de Biologia, eu lembro, eu fui um dos que puxou a Feira de Ciências no segundo ano e sempre gostei e já tinha meio que definido no Ensino Fundamental que era isso que eu queria, e no Ensino Médio foi só para confirmar mesmo que eu queria ser professor. (HVPL)

A disciplina de Ciências/Biologia na formação primária e secundária, respectivamente, também apareceu com destacado papel na constituição dos docentes pesquisados. Nota-se, no entanto, pelos recortes apresentados a seguir, que não é simplesmente pelo fato de cursar as disciplinas de Ciências ou Biologia que estas se tornaram importantes na sua constituição como professores. Isto ocorreu, especialmente, por serem conduzidas por um docente que se utilizava de uma estratégia (o desenho, no caso) que destacava e dava sentido aos conteúdos disciplinares, revelando aqui a importância da metodologia e da transposição didática.

Os desenhos no quadro. Os desenhos da professora (de Biologia), o que ela desenhava... eu peguei o que tinha menos matemática, e juntei: vou estudar as plantas (Agronomia), vou estudar os animais (Veterinária), vou desenhar bastante (Artes), fiz Biologia! Tem tudo! (risos). (HVPS)

$\mathrm{Na} 4^{a}$ série nós aprendemos a célula. Fizemos o desenho da célula que a prô fez no quadro, então, isso me chamou bastante a atenção. (HVPL)

Colocando-se foco na graduação, enquanto momento fundamental na formação do professor, têm-se evidências, na análise dos excertos, de diferentes formas de inferência. Para o Professor Lucas, a graduação, apesar de um importante momento de formação, não cumpriu suficientemente o papel de prepará-lo para a docência. Para a Professora Simone os saberes da graduação relacionam-se às lembranças de professores e aos conteúdos aprendidos, que foram aprimorados ou ressignificados na experiência, influenciando na transposição didática dos mesmos para conhecimentos escolares mais aproximados da realidade do aluno. "Da graduação saí perdida" (ENTPS). De alguma forma, tanto a Professora Simone quanto o Professor Lucas mencionam a necessidade de maior articulação teoria-prática na graduação. A primeira, em função de maior aproximação de sentido de conhecimentos teóricos com conhecimentos práticos (aplicáveis); o segundo em ter maior formação prática, nas escolas onde efetivamente se dará o atuar pedagógico do professor. Ainda se analisando esse contexto, percebe-se que os professores da graduação exercem influência, considerada fundamental na visão do Professor Lucas, de modos diversos, mas, sobretudo pelos profissionais que são (as atitudes), muito mais do que pela disciplina que ministram (pelos saberes disciplinares que mobilizam). Notam-se algumas permanências de fundo na análise dos excertos produzidos pela Professora Simone e pelo Professor Lucas ao se referirem à época da graduação (em Ciências Biológicas):

Me lembro dos professores conversando com a turma. O ADI, uma paixão. A BRA. Com o 
ADI? Como é que eu ia colar com o ADI se ele era meu amigo? Eu não podia colar. Sabe? Eu tinha sempre essa visão. [...] (HVPS)

Então esses dois fatores: amizade e posicionamento em relação aos professores e como tu quer ser. Bom eu tenho uns três que foram marcantes: BRA, MAG (biologia molecular conhecimento), RAF (algumas atitudes) - marcaram, foram importantes durante a minha trajetória). (HVPL)

Outra vertente que se fez importante na análise dessa categoria foi a influência dos pares, considerados no contexto deste estudo, todos os colegas de profissão que, de alguma forma os influenciam, especialmente professores de sua área, e, ainda, de campos disciplinares diferentes. Nesse sentido, o Professor Lucas reconhece essa convivência como fundamental para a constituição dos saberes de um professor, configurando uma espécie de formação continuada. A Professora Simone nomeia e faz menção pontual a uma colega que a auxiliou na formação de saberes que enriqueceram sua prática:

Teve uma pessoa que me ajudou muito, CIN, foi fazer mestrado. Depois veio para a escola e eu era meio na minha, e ela veio com uma proposta de a gente fazer um projeto, foi então que eu comecei a me envolver nesses projetos [...] (ENTPS)

Assim como é possível perceber a influência dos colegas, da equipe de professores, gestores que fazem uma escola, dos pares, enfim, é oportuno pontuar a influência das atividades nas aulas de Biologia no ensino médio para atrair novos professores para esse componente curricular. Nesse caso destaca-se a experimentação didática, ou seja, as professoras exploraram o ambiente dos alunos (o principal rio que banha o município onde estes moram) para criar uma situação de aprendizagem significada e contextualizada, como se extrai do excerto a seguir:

[...] Íamos com os alunos reconhecer ecossistemas de Passo Fundo (o rio, as nascentes). No final do ano fazíamos um simpósio socioambiental (foi lá pelo ano 2000). Surgiu muito aluno na Biologia da UPF vindos aqui da Escola nessa época. Veja, é o professor que faz isso. (ENTPS, grifo nosso)

Este trabalho em colaboração que envolve os processos de mediação coletiva abordados por Acosta (2013), também é relatado como constituinte da profissional destacada que se tornou a Professora Simone, na análise do seguinte recorte: "Para os trabalhos peço ajuda" (ENTPS), referindo-se à contribuição dos pares em sua formação, como colegas e gestão, em momentos de formação formal ou não. A mesma visão é expressa por Cunha (2011), com base em sua pesquisa com bons professores: "Alguns dos sujeitos referiram-se à influência de colegas professores. Apontaram a observação de aulas e as discussões em grupo como elemento importante para sua prática docente" (p.81).

Na mesma direção, a prática do dia a dia na sala de aula apareceu como vivência fundamental da constituição dos saberes destes professores que têm sua prática destacada na docência de Biologia: "Só que, realmente, todos os momentos que eu tive lá me ajudaram [referindo-se à Graduação], mas tudo isso vai acontecer na prática" (ENTPL), respondendo à interrogação sobre "que acontecimentos/situações/momentos 
acredita terem sido importantes para que se tornasse o professor de Biologia que é hoje". A prática, ou os saberes experienciais dos sujeitos de pesquisa, corroboram as afirmações de autores como Tardif (2000, 2012), Gauthier et al. (1998), Pimenta (2012), sublinhando a importância destes saberes na constituição dos professores.

$\mathrm{Na}$ última vertente de análise da categoria em questão (constituição dos saberes do professor de Biologia), reflete-se sobre a influência da formação continuada e de atividades de extensão. Como forma de perceber a importância dos processos vividos na constituição dos professores após a conclusão de sua graduação, solicitou-se que os sujeitos narrassem aspectos/características suas, que acreditam terem sido importantes para que fossem indicados como bons professores de Biologia no referido período.

No que concerne à formação continuada, é evidente a sua importância para ambos os sujeitos, reitera-se com o Professor Lucas ao afirmar que "ajudou em tudo porque nós somos a nossa formação" (ENTPL). Quanto à formação continuada especificamente por meio de cursos de pós-graduação foi referido no discurso dos sujeitos de pesquisa que:

A graduação te dá as matérias, na sala aprendi a fazer os links da matéria. Em relação à pós-graduação, ela me confirmou as coisas que eu fazia...as dúvidas, os medos, "opa isso eu faço certo, isso errado". Me deixou mais segura. (ENTPS)

Porque se tu estacionar não tem como tu prosseguir, então eu vejo que é bem isso, [a importância] da formação continuada, para prosseguir. (ENTPL)

Analisar estes excertos faz reconhecer a importância da formação continuada para a constituição dos saberes destes sujeitos, levando a crer que se destacam na docência porque não deixam de buscar o crescimento, o aprofundamento teórico e prático, para o seu fazer pedagógico e para o sentido de ser professor. Ambos pontuaram a participação em programas, projetos, feiras, cursos, dentre outros, como momentos marcantes em sua constituição enquanto professores.

As atividades de extensão, ou seja, todas aquelas que influenciam a prática do ensino de Biologia, mas não estão formalmente assentadas em processos de formação, como, por exemplo, o convívio com grupos sociais distintos, organizações, meios culturais, dentre outros, também exercem influência na constituição dos saberes destes destacados professores.

Do mesmo modo como percebeu-se tais aspectos na forma como se constituíram os professores Simone e Lucas, buscou-se compreender como eles mobilizam seus saberes para a prática docente, tarefa a que nos dedicamos na sequência.

\section{A Mobilização dos Saberes dos Professores de Biologia}

Como sinalizam Gauthier et al. (1998), é preciso "compreender melhor como fazem aqueles que ensinam com um certo sucesso" (p.76). Assim, a compreensão dessa variável foi buscada, primeiramente, pelo entendimento da experiência colocada em prática. Nesta categoria temática abordam-se as situações emergentes dos dados que identificam os sujeitos de pesquisa em momentos diferentes de sua trajetória profissional, 
utilizando-se da descrição das fases da carreira proposta por Huberman (2007), e como vão mobilizando diferentes saberes para dar conta de sua tarefa de ensinar Biologia. Assim, empreendeu-se a atenção em tomar as falas e as observações dos sujeitos de pesquisa considerando que a Professora Simone tem 25 anos de experiência em sala de aula e o Professor Lucas, pouco mais de três anos, conforme os registros obtidos no ano de 2014. A primeira já aprendeu-fazendo e tem clareza sobre quais saberes consegue melhor "dominar", usando-os para conduzir o processo de ensinar em estreita relação com o aluno. Nesse sentido, como afirma Tardif (2012), "as relações com os alunos constituem o espaço onde são validados, em última instância, sua competência e seus saberes" (p.51). O Professor Lucas, por sua vez, encontra-se na fase da "entrada na carreira". Não menciona o choque de realidade que é comum acontecer neste período, mas demonstra o aspecto da descoberta (Huberman, 2007) e, em consequência, a sua busca por explorar (consciente ou inconscientemente) quais saberes pode/deve mobilizar para garantir sua prática pedagógica, é o seu entusiasmo, o seu orgulho, transcritos no excerto a seguir.

O professor tem várias coisas que recompensam, por mais que tu possas não ter um bom salário, mas sentir que o aluno gosta de você, no sentido de afeto, de carinho, tu encontrar na rua e ver "aquele foi meu aluno", é bastante recompensador. (ENTPL)

Esta mobilização situada de saberes - em relação ao tempo - pode ser evidenciada, por exemplo, nos excertos de observação de aulas, a seguir, que demonstram nítidas diferenças na forma de mobilizar saberes para dar conta de ensinar o conteúdo:

A: Professor o que é aquelas anteninhas que o senhor não falou? [refere-se a uma constrição do cromossomo que aparece nos desenhos do slide].

P: Nós acabamos de falar anteriormente. Qual a função da região organizadora do nucléolo? Região dos cromossomos que faz a síntese então do RNA ribossomal. E o telômero também é a ponta do cromossomo, se relaciona ao tempo de vida de uma célula. Todo telômero, como se fosse um relógio molecular, a cada divisão celular ele vai acabar perdendo um pedaço, certo? Então o telômero é o relógio molecular que vai determinar a idade do indivíduo. No ano de 1997 foi feita a clonagem da ovelha Doly, e a ovelha Doly ela foi sacrificada lá em 2000 ou 2001. [...] (OA1PL)

A: E ter filhos com os primos?

P: Tipo assim, a Síndrome de Down, dois primos casam e deu o acaso de nascer uma criança, é mais pela idade da mãe - se a mãe é muito jovem ou muito velha, daí é mais frequente ter a síndrome, entende? Os óvulos não estão bem organizados, ou velhos demais, agrotóxicos, alimentação, aditivos químicos... a mulher fica exposta. Ainda na barriga da mãe ela tem todos os óvulos, se eu tenho 45 anos, eles estão aí há 45 anos expostos a tudo. Então, quanto mais velho for, mais condições de ter uma criança com problemas, os raios alfa, beta, os aditivos, os agrotóxicos. Ainda mais agora que a gente tá usando muito alimento industrializado, e a gente compra pelo olho. Né? Vai lá na feira, o tomate orgânico e o outro, qual é o mais bonito? O outro. Por que? Porque tem 
mais veneno. Vai comprar cenoura, tu pega sempre a maior. A pequenininha parece que não presta. Ela é pequena porque absorveu menos agrotóxico, é mais saudável. Tá? (OA1PS).

Os recortes demonstram que o Professor Lucas (novato) em relação à Professora Simone (experiente), opera no campo de atuação onde se sente mais confortável, ou seja, no manejo do conteúdo, utilizando inúmeros termos técnicos. Evidencia dificuldades em trabalhar fora do planejado, em lidar com o inesperado (por exemplo, com as mais variadas perguntas dos alunos e suas particularidades), em flexibilizar em virtude de uma situação elementar. A Professora Simone, por sua vez, na medida em que trabalha o conteúdo opera, confortavelmente, ao encontro das perguntas dos alunos, lançando mão de exemplos que familiarizam o conteúdo em seus contextos, traz os alunos para si (relacionando o conteúdo com os pais, os tios, os avós, a família, enfim), muito mais que o conteúdo, pura e simplesmente, para eles. A contribuição da experiência na mobilização dos saberes foi destacada pelos próprios sujeitos de pesquisa:

Eu acho que a cada ano tu melhora mais. Quando tu trabalha a primeira vez com um conteúdo, a segunda vez, na segunda tu vai fazer diferente. [...] Então essa questão da experiência e tu buscar, faz com que tu se torne um professor melhor [...] essa busca, essa experiência e tu refletir sobre a tua prática faz com que tu melhore [...] Eu percebo que do ano passado para esse ano eu tô muito melhor, e cada vez tu tá melhor; e tu tá estudando, e procurando coisas novas (ENTPL, grifos nossos).

(Ia dar aula muito tensa), agora sou divertida, eles não cansam. Eu dava mais nos dedos (eu tô mais light) com essa história de processo. (ENTPS, grifos nossos)

É no referencial teórico que consubstancia essa análise - especialmente em Tardif (2012), Schön (1995a, 1995b, 2000), Perrenoud (2001, 2002), Cunha (2011) e Pimenta (2012), que se ressalta a importância da reflexão sistemática da prática docente para que o professor racionalize seus saberes experienciais e, a partir disso, objetivando-os, mobilize-os em seu fazer. Em outros excertos também é nítida a consciência do Professor Lucas (novato), sobre a importância desta reflexão, enquanto que para a Professora Simone não se evidencia essa necessidade.

E tu vai resolver, tu não vai buscar em algum livro essa solução, tu vai se embasar numa coisa, mas para isso tu vai refletir sobre a tua prática, sobre aquilo que aconteceu naquele momento. Então a formação continuada, todos esses cursos, e também a escola é o principal local de formação, com os acontecimentos que tem; a própria sala de aula é um local, o maior local de nossa formação, que a cada situação tu vai se formar, vai refletir, tu vai mudar, tu vai se transformar. Então eu acho que formação continuada é fundamental, se refletir sobre a tua prática. (ENTPL)

Analisar este último recorte, especialmente, faz-nos voltar à importância da reflexão sobre a prática nos momentos de formação continuada, endossando uma das hipóteses que moveu esse estudo: a formação continuada baseada na epistemologia da prática é um caminho viável para qualificar a ação docente, especialmente na objetivação 
de saberes experienciais. Nesta direção, para Pimenta (2012), "a formação de professores na tendência reflexiva se configura como uma política de valorização do desenvolvimento pessoal-profissional dos professores e das instituições escolares" (p.35).

Outro aspecto que emergiu da análise dos dados, de forma distinta para os professores em diferentes fases da carreira, diz respeito à flexibilidade e tolerância. $\mathrm{Na}$ visão de Huberman (2007), ao avançar em sua carreira e construir um sentimento de segurança e conforto em sua atuação, o professor aposta em maior flexibilidade na gestão da turma, relativizando os insucessos, em função de uma sensação de "estar à vontade no plano pedagógico" (p.41). A Professora Simone trabalha a gestão da classe sem que haja situações de grande tensão ou conflitos, e sem precisar recorrer a métodos de punições eventuais, utilizando-se do termo empregado por Gauthier et al. (1998), quando aludem ao emprego de medidas disciplinares. Ela faz, inclusive, referência em preferir a turma mais "barulhenta", mas que pergunta mais, em detrimento da mais calma, que "às vezes lhe dava tédio" (ENTPS). Postura típica da fase de diversificação, diferentemente da fase de entrada, onde o professor ainda tateia os modos de "manter" a turma em condições de aprendizagem, exigindo silêncio e disciplina a todo o tempo.

Em relação a essa diferença de estágio na carreira, ainda pode-se inferir que os modos de planejar dos dois professores apresentaram-se distintos. O Professor Lucas, apesar de não ter como hábito a escrita sistematizada de diários de planejamento, o faz de modo mais informal, utilizando-se de meios digitais, inclusive disponibilizando aos alunos, previamente, conteúdo em rede social. A Professora Simone, em contrapartida, "flexibiliza" o momento de planejamento de tal modo que diz planejar, mas não mais como o fazia há anos atrás.

Outra vertente analisada para compreender como os professores mobilizam seus saberes foi o modo como conduzem a gestão da classe. Consoante às atividades de planejamento de como gerir a classe, com algumas considerações já tecidas no item anterior, a Professora Simone faz menção de não mais necessitar realizar o planejamento formal da aula (planejando, por exemplo, as formas de gestão da classe), permanecendo, no entanto, o hábito de revisitar o conteúdo para qualificar a gestão da matéria. $\mathrm{O}$ Professor Lucas, de outra parte, sistematiza o seu planejamento utilizando-se do computador, organizando e atualizando conteúdos.

No que se refere à condução das atividades, buscou-se evidenciar aspectos de como os professores mobilizam seus saberes em relação aos espaços que ocupam para o processo de ensino-aprendizagem; como se deslocam na sala de aula, buscando a interação com os alunos; das relações/atitudes que o professor estabelece com eles para ensinar, se comunicar, resolver conflitos, estabelecer limites. Pela triangulação dos dados percebe-se que os sujeitos de pesquisa ocupam o espaço da sala de aula em detrimento do uso de outros espaços, como o laboratório de informática e de Ciências, o pátio ou outros locais externos à sala de aula, como forma de melhor conduzir a turma e "vencer o tempo e o conteúdo". A Professora Simone informa que esses espaços existem, estão disponíveis, mas indica variáveis (como o pouco tempo e a grande quantidade de alunos) 
que os colocam em desvantagem para a utilização em relação à sala de aula. Veja-se:

O laboratório de informática tá aberto, eu até posso levar, mas não tem ninguém cuidando... então como tu vai levar? Tu é responsável...eu desisti de levar. (HVPS)

O laboratório da escola é bom, pois conta com a estrutura que suportava os cursos técnicos de antigamente (bancadas, etc.), agora as meninas do PIBID estão revitalizando o laboratório. (ENTPS)

Tal constatação parece sublinhar os aspectos lacunares do ensino de Biologia, pontuados anteriormente, especialmente os que se referem às dificuldades de proceder à experimentação didática e, por assim ser, operar na condução da aula de Biologia essencialmente expositiva, colocando em questionamento, inclusive, a ocorrência da interdisciplinaridade e da construção do conhecimento.

No que diz respeito aos aspectos atitudinais que contribuem para a gestão da classe, é significativo o destacado pela Professora Simone que reconhece a importância da disponibilidade, do carisma, da descontração, do bom humor ("sou divertida", diz ela em sua entrevista) e da capacidade de despertar a curiosidade. Nos relatos do Professor Lucas, embora menos evidentes, também se encontram esses aspectos, quando promove a interação com os alunos por meio da brincadeira, incluindo a contação de piadas e o uso de paródias como método de ensino. Gauthier et al. (1998), balizando os achados da pesquisa em relação à mobilização de saberes para a gestão da classe, também pontuam que os professores mais bem-sucedidos se utilizam do humor e promovem interações que influenciam favoravelmente o aluno.

Destarte à importância que o Professor Lucas atribui ao conhecimento do conteúdo, saberes pedagógicos como o comprometimento e a ética do professor em sala de aula, também são pontuados como relevantes. Os saberes curriculares, que se referem às normas, regras e discursos perpetuados pela instituição escolar, denotando a importância da disciplina e de atitudes de escuta por parte dos alunos, são mobilizados pelo Professor Lucas com relativa frequência - pedido de silêncio, organização, ordem, determinando quem escuta, quem fala. Obtém, assim, o "silêncio" da turma e a participação dos alunos, de forma mais verticalizada. De igual modo, utiliza-se para obter essa atenção, de técnicas de exposição de conteúdo e questionamentos constantes. A Professora Simone, por sua vez, opera com estas questões ainda em clima de amistosidade para "chamar a atenção" dos alunos que estavam a conversar, demonstrando a forma descontraída como busca chamar o aluno para si.

Não de modo comparativo, mas sinalizando a trajetória própria de cada um, a preocupação com o aluno em si não é demonstrada da mesma forma pelo Professor Lucas. Percebe-se esse direcionamento quando os alunos "continuamente reclamavam do calor e pediam para encher as garrafinhas de água. [...] Muitos lutavam contra o sono, fazendo grande esforço para manterem-se de olhos abertos e prestando atenção" (OA1PL), e o professor não atendeu a esses anseios, respondendo negativamente, chamando-os ao conteúdo e solicitando o silêncio que julgava necessário. Ainda de 
modo um pouco diferente, o Professor Lucas empreende modos de conduzir a gestão da classe, especialmente no que diz respeito à manutenção da ordem, do silêncio entendido como necessário para a aprendizagem. Em diversas comunicações e atitudes demonstra a necessidade de que se estabeleça essa condição, mobilizando recursos que, por vezes, denunciam sua expectativa de manter a classe disciplinada. $\mathrm{O}$ uso de saberes atitudinais também é expresso na condução de certos conteúdos, mobilizados em diversos momentos pela Professora Simone e pelo Professor Lucas em atuação na sala de aula, durante as observações e destacado no relato obtido durante a entrevista:

Teve uma ocasião que eu estava fazendo um Projeto com alunas daqui da Escola, eu sentia que as meninas não sabiam fazer nada em casa [...] e tem uma escassez muito grande de empregadas domésticas; então eu ensinava desde receitas, dicas de limpeza, remoção de manchas - era o Projeto Praticidade da Vida Moderna. Num certo dia fizemos um bolo e precisávamos de uma forma com um furo no meio, não tinha, então eu coloquei um copo no centro da forma, e ficou o bolo com o furo no meio. No final do ano a diretora chamou as alunas e eu e nos colocou em formato de um júri para avaliação, e pediu que as meninas falassem do projeto e da professora: teve uma que disse: "Eu aprendi com a Profe Simone que na vida tudo dá". Eu fiquei conhecida por essa frase - eu chamava então "projeto tudo dá”. (ENTPS)

Uma das situações, das coisas que está acontecendo é que alguns alunos estão sempre com chiclete: então do segundo semestre em diante foi uma percepção que tu entra na sala e tem que dizer: "vamos tirar o chiclè", e aqui não tem ruminante e não quero saber de ninguém com chiclete. Então tinha uma situação assim, na aula quando eu falei de ruminante, eles: "o que que é isso?", a gente não tinha trabalhado ainda. Então expliquei que o chiclete é uma questão de respeito, que tu tem o momento certo, sala de aula não é, e também que tu tem a questão de saúde. Daí surgiu aquela história que as mães dizem, os avós, se chiclé "gruda nas tripas" ou não. Então coisas nesse sentido eu posto no grupo e eles leem e se torna bem interessante. Eles comentam ou eu percebo que eles ficam felizes com isso, de uma forma diferente. (ENTPL)

Outra forma de mobilizar estes saberes atitudinais, por vezes em detrimento de saberes disciplinares mais formais ou como forma de qualificá-los, se pode perceber nos registros da OA3PS, quando o assunto AIDS foi trabalhado por meio de uma dinâmica de sensibilização dos alunos para a questão, utilizando-se como pano de fundo a música "Como uma onda", de Lulu Santos. Partes desse momento se pode observar no excerto, em que a professora intercaladamente fala e canta aos alunos, todos sentados em círculo no chão. Importa pontuar que, ao cessar a música todos batem palma, logo dá o sinal, alguns alunos recolhem suas mochilas e saem. Outros abraçam a professora e algumas alunas dizem: "foi a melhor aula que eu já tive profe" (OA3PS); "que aula ótima" (OA3PS):

"Quem espera que a vida seja feita de ilusão, pode até ficar maluco, ou morrer na solidão, é preciso ter cuidado, para mais tarde não sofrer", é preciso saber viver agora. Repito, não vão deixar de viver, ou aproveitar a vida o melhor que puder, mas não coloquem pedras no caminho, vou retirar as pedras do meu caminho, vou tirar os espinhos, para que vou 
procurar, como dizem, sarna para me coçar, se eu posso escolher. "É preciso saber viver", eu posso curtir a vida sendo educado, eu posso curtir a vida sendo gentil, sendo careta, colocando as classes no lugar, dando bom dia, boa tarde, boa noite e não pegando AIDS. (OA3PS)

Ao se analisar esta atividade, e os demais dados postos até aqui, parece evidenciarse que os saberes atitudinais são mobilizados pela Professora Simone com grande frequência para a condução da aula. Estes dão sentido ao conteúdo pela sensibilização dos alunos, caracterizando a gestão da classe como fundamental a esse professor que se destaca em sua prática pedagógica. Pontua-se que, para essa professora, tais aspectos sobressaíram-se também como importantes na sua formação enquanto docente (formação primária e secundária, essencialmente).

Os sujeitos de pesquisa destacam a influência de antigos professores nos modos de gestão da classe e mobilizam saberes pedagógicos que obtiveram (e mantêm na lembrança) dos momentos da formação básica, como por exemplo:

Não gostava do MO (professor de microbiologia) e do PA (professor de Anatomia), é que eles não conversavam com a gente. E com eles eu colava, colava - porque eles colocavam a gente naquele anfiteatro de ponta a cabeça, eles não confiavam em mim? Então eu colava. [...] A BR, até hoje, ela falava vice-versa e eu copiei ela...até hoje eu digo para os alunos vice-versa. (ENTPS)

Lembro da minha professora de Português que falava: "Isso é uma ordem e não um pedido" e eu falo isso. (ENTPL)

Pode-se sintetizar, assim, que a Professora Simone demonstra manejar confortavelmente com os saberes básicos de gestão da classe. Traz os alunos para si pelo relacionamento que estabelece com os mesmos, que lhe dá a liberdade de ser afetuosa, carismática, utilizar-se do humor e da brincadeira para ensinar o conteúdo, contextualizando-o de acordo com a realidade da turma. O Professor Lucas, diferentemente, parece ter optado pelos saberes básicos de gestão da matéria - opera confortavelmente trazendo o aluno para si, pela profundidade e destreza com que aborda o conteúdo na sala de aula, as nomenclaturas próprias da Biologia são faladas, mostradas, exercitadas, aprofundadas, testadas e, assim, conduz e destaca sua prática, como se vê a seguir.

Na categoria da gestão da matéria, que conforme Gauthier et al. (1998) e Tardif (2012), contempla os saberes que o professor mobiliza para ensinar e qualificar a aprendizagem dos conhecimentos inerentes à disciplina de Biologia ao longo do ensino médio, destaca-se, por exemplo o planejamento de conteúdos. O Professor Lucas dá maior significado ao momento de planejamento do conteúdo em relação à Professora Simone, como já abordado. A busca pela atualização do conteúdo é mais evidente para o Professor Lucas, em comparação à Professora Simone. É nos momentos de planejamento, também, que o professor organiza os conteúdos que são disponibilizados aos alunos por meio da rede social Facebook, buscando ir além do livro didático e do material que 
apresenta em sala de aula, incentivando a leitura de materiais organizados e compilados pelo próprio professor:

Agora só tenho $1^{\circ}$ ano, só de tarde (faz 3 anos) - estou sentido falta do segundo e terceiro. A gente fica com a cabeça mais aberta - tô me sentido meio com medo do $2^{\circ}$ ano....se um dia tiver que voltar, não sei se sei ainda o conteúdo. (ENTPS)

Geralmente eu planejo o conteúdo indo para sites, para livros, tento dar uma olhada numa bibliografia e na outra faço um material, vejo se tem alguma prática que se encaixe, alguma coisa diferente, também nas paródias, eu procuro ver se tem algo que se encaixe no conteúdo. Às vezes por causa do tempo, então em alguns momentos também nem tudo eu vou falar em aula, nem tudo eu vou conseguir, então essas reportagens, esses negócios que chamam atenção deles eu acabo postando para eles pesquisarem, lerem. Teve esses dias no Globo Repórter sobre o sistema nervoso, então eu postei no grupo. (ENTPL)

Esta preocupação com a atualização e o dinamismo do conteúdo é verificada para além do processo de planejamento. Cita-se alguns fatos que corroboram esse achado, por exemplo, o Professor Lucas disponibiliza no setor de cópias da escola, com grande frequência, conteúdos para serem aprofundados, bem como em meio virtual, utilizando-se da rede social Facebook (ENTPL; OA1PL; OA2PL). O material utilizado em sala de aula e os termos proferidos pelo professor dão vistas de aprofundado conhecimento na área de Ciências da Natureza e suas Tecnologias (OA1PL; OA2PL; OA3PL). Além do aprimoramento, o domínio do conteúdo é enfatizado pelo Professor Lucas como característica essencial, embora não única, para ser bom professor. A Professora Simone, por sua vez, preocupa-se mais com a forma como vai apresentar o conteúdo, e não com a sua atualização, profundidade ou domínio, buscando despertar a curiosidade do aluno para o mesmo, destacando-o pelas formas de gestão da classe, como anteriormente discutido. A Professora Simone manifesta em seu relato que não se sente segura quanto ao domínio da matéria, por isso esboça o hábito de, apesar de todo o seu tempo de experiência (25 anos), ainda "dar uma estudadinha" antes de ir para a escola. Como se pode analisar, isso não parece falta de segurança como ela considera, mas até mesmo o bom hábito do planejamento, sistematizado ao seu próprio modo; responsabilidade para com o ato de ensinar; e a "predileção" que a Professora Simone manifesta em relação à gestão da classe, campo em que se sente segura para atuar. A Professora Simone não recorre simplesmente a uma "estudadinha", mas a uma busca em sua bagagem como aluna, filha, mãe, enfim, enquanto ser humano situado social e historicamente em interação com os demais, realçando seu espírito curioso e investigativo que a torna a professora destacada que é.

Outra preocupação do Professor Lucas que aparece latente em suas narrativas é com o vestibular e o ENEM, bem como com a importância de determinado conteúdo por ser pré-requisito para a assimilação de outro - evidências que não se registram na triangulação dos dados para a Professora Simone, que com pouca ênfase manifesta a preocupação com estes momentos pontuais na vida do aluno (ENEM, vestibulares, conforme já apontado em excerto anterior). Na mobilização de saberes que deem conta 
de bem ensinar os conteúdos biológicos, o Professor Lucas pontua uma situação que demonstra o seu rigor e sua preocupação com a gestão do conteúdo - a afinidade do professor com determinados conteúdos e não outros. Tal condição não é expressa pela Professora Simone.

Os conteúdos de Biologia, para além dos aspectos conceituais e atitudinais, precisam englobar os de cunho procedimental (conteúdos procedimentais). Aparece de modo tímido este tipo de conteúdo na prática dos sujeitos pesquisados. Acredita-se, analisando-se os excertos a seguir, que estes não valorizam situações de aprendizagem em que esse tipo de conteúdo poderia ser trabalhado. A Professora Simone, por exemplo, não explorou com mais afinco o conteúdo procedimental na apresentação dos trabalhos, deixando de mostrar aos alunos as formas academicamente aceitas para lhes conferir rigor científico. Nesta direção, no entanto, em outra aula, a observação permitiu identificar que a Professora Simone se preocupa em explicar o porquê do uso de papel machê e de material reciclado, explica e motiva os alunos a (re) utilizar a cola que havia sobrado de outro grupo para a realização do trabalho, passando noções referentes à sustentabilidade. Ensina os passos de como fazer e apresentar um trabalho (OA2PS). Já o Professor Lucas, ao indicar um trabalho em grupo sobre a evolução das plantas, também o fez de modo normativo, sem abordar o procedimento inerente ao trabalho como produção acadêmica, como construção de conhecimento.

Seguindo nos modos de gestão da matéria, tornam-se importantes os momentos de avaliação da aprendizagem. Percebeu-se o empenho dos professores para operar com diversos instrumentos de avaliação, para além da tradicional prova, utilizando em especial o trabalho de grupo (OA2PS e OA3PL). O uso desses recursos, por ambos os professores, é um indício de que a avaliação se dá na direção de classificação, de atribuição de nota em si, e não no sentido da emancipação do aluno que, por meio da ressignificação do erro, constrói conhecimento. No entanto, pode ter contribuído com o fato de ter que "dar aula", a presença da pesquisadora, para mostrar como o faz. Ainda se tratando dessas atividades (a construção da célula e a construção da árvore filogenética), o professor pode mobilizar saberes conduzindo as atividades na concepção da experimentação didática. Todavia, a experimentação didática, como situação de aprendizagem com vistas à construção do conhecimento, não parece estar suficientemente objetivada para os sujeitos da pesquisa. Existe, ao contrário, uma concepção de aula prática somente possível em laboratório, evidenciando um "desabafo" sobre as condições de trabalho e a organização do ambiente escolar que não são facilitadores da experimentação didática, assim como vem sendo elencado por diversos autores (Martins \& Leite, 2013; Marandino, Selles, \& Ferreira, 2009). Não se quer dizer, todavia, que os professores nunca fazem uso da experimentação didática. Fala-se em preponderância das aulas expositivas, mas não de exclusividade. Fala-se da utilização da experimentação, no entanto, supõe-se que não haja a objetivação de atividades como tal. A Professora Simone, por exemplo, adota uma metodologia ativa para o estudo do paramécio, incentivando que os estudantes façam uso de jingle, dramatização e simulação de uma comunicação radiofônica para 
apresentar o tema aos colegas (OA1PS).

No que concerne à opção, o gosto e a realização profissional na docência, última vertente em que se analisa a mobilização dos saberes docentes, é recorrente nas narrativas de ambos os sujeitos de pesquisa, o querer ser professor como uma escolha consciente, assim como o gosto pela docência. Pode-se dizer que são as evidências mais latentes que caracterizam a ambos os sujeitos de pesquisa, singularizando-os. É interessante observar, no que diz respeito à opção por ser professor, a narrativa do Professor Lucas referindo-se à escolha de sua profissão como obra do destino: "Parece que a gente tem um destino, que foi destinado para isso, que não foi algo assim da noite pro dia” (HVPL). No entanto, logo recobra sua trajetória de vida e reconstitui a justificativa:

Eu esperei porque eu sempre tive essa vontade ser professor, então eu esperei depois de concluir o Ensino Médio para fazer Licenciatura. Porque o vestibular para Licenciatura só ocorre na metade do ano (Vestibular de Inverno). (HVPL)

A pergunta era porque eu escolhi? Conforme eu já respondi, desde pequeno eu já tinha essa ideia, já pensava em ser [...] (HVPL)

Ao ser indagado sobre "o que, ou quem, mais contribuiu para que se tornasse o professor de Biologia que é hoje?”, responde: "Minha vontade própria de ser professor" (ENTPL). Essa posição - a escolha por ser professor e não se tornar professor por falta de outra opção, ou pela facilidade de ingresso ou em função de outras motivações que não o desejo próprio - é assumida pelo Professor Lucas também para justificar um aspecto lacunar da educação na atualidade, que é a desqualificação dos processos educativos, por vezes, parece em decorrência da atuação de professores descompromissados com sua profissionalidade. O gostar de ser professor também é um aspecto que aparece muito forte nos relatos analisados, influenciando na realização profissional dos sujeitos de pesquisa.

Eu amo ser professora. Eu amo o Ensino Fundamental, porque eles são sinceros [...] me sinto realizada. (HVPS)

Talvez em decorrência dessas duas variáveis - optar por ser professor e gostar de sê-lo - a realização profissional também é manifestada pelos sujeitos de pesquisa. É mencionado pela Professora Simone que o que contribui para esta satisfação é a presença, o contato com o aluno. Parece que é este gostar e essa realização que fazem com que, em sala de aula, nos momentos observados, ou nos casos relatados, se perceba como nítida a mobilização de saberes dos docentes em sala de aula na busca e na valorização da interação com o aluno. Apesar de extenso, vale apresentar o excerto a seguir para compreender-se a importância que a Professora Simone concede ao fato de seus alunos lhe terem retornado à comunicação de que não seria mais professora da turma, com uma salva de palmas:

Esse ano foi muito interessante para mim - eu tive que largar as turmas 105 e 106, consideradas turmas meio danadas, nenhum professor gosta de dar aula lá. E eu...na minha última aula com eles eu fiz uma aula, expliquei como tinha explicado em todas 
as outras. Disse que seria minha última aula, em função da redução, [ao final recebi] um aplauso sincero...de lembrar eu me arrepio. Eu já tinha falado a mesma coisa nas outras salas, do mesmo jeito e não recebi o aplauso. Eu não sei se foi emoção porque era a última aula, mas acho que foi todo um contexto. A primeira turma me aplaudiu e eu pensei "que amados, que queridos". Na segunda turma eu fiz a mesma conversa, dei a mesma explicação, eles também me aplaudiram. Eu não sei se é porque uma turma é do lado da outra e eles escutaram o aplauso e aplaudiram também. Mas as duas turmas aplaudiram, tipo assim: "tchau, muito obrigada, sabe?". E é esse retorno que me faz ser professora. (HVPS)

[...] Todos participam, a grande maioria se anima, interagem, e vão levando as coisas [...] Esse é o diferencial que te deixa animado, ter o retorno. (ENTPL)

Com essas inferências que sintetizam os modos como os sujeitos de pesquisa mobilizam saberes na sala de aula do ensino médio para ensinar Biologia, apresenta-se as considerações finais que acenam não para o fim da linha, mas, acredita-se, para novos caminhos.

\section{Considerações Finais para Novos Inícios}

$\mathrm{Na}$ busca por formatar um texto que encerre as principais concepções perpassadas no decorrer dessa investigação e expresse as respostas basilares que com ela obtivemos, retomamos, de início, o objetivo da pesquisa, que foi o de compreender como os professores de Biologia constroem e mobilizam seus saberes docentes na prática pedagógica.

Utilizamo-nos dos estudos de Gauthier et al. (1998) para justificar a (pequena) trajetória de nosso estudo diante de um caminho tão vasto como se apresentou o dos saberes docentes, o que nos faz compreender o risco imenso de aventurar-se por este terreno, verdadeiro campo minado para o caminhante imprudente. Por isso, na busca pelas respostas trazidas na direção deste objetivo, permanecemos num nível de profundidade seguro, sem incorrer no risco de fazer afirmações genéricas e de apontar certezas inconsistentes, mas nos preocupando em perceber que percursos desenvolveram esses professores que têm sua prática diferenciada, sem a pretensão de que os dados que ora se apresenta sejam generalizáveis. São saberes que, advindos desta pesquisa, revelam um caráter provisório, por isso, passíveis de novas retomadas para novas considerações.

Principiamos por abordar as respostas à seguinte interrogação: como se constituem os saberes destes professores de Biologia? Os saberes destes professores se constituem pela influência da família/infância/adolescência e grupos sociais; pela influência da formação oficial (primária, secundária, superior/graduação); pela influência dos pares em situações profissionais; e, pela influência das práticas de extensão/formação continuada, revelando singularidades e regularidades no modo de constituição. A busca pelas singularidades particulariza o modo de constituição dos saberes dos sujeitos de pesquisa, notadamente, em relação à espécie de saberes que trazem à tona. Para o Professor Lucas prevalecem saberes disciplinares - os que dizem respeito ao conteúdo do 
ensino de Biologia em si, ao passo que para a Professora Simone prevalecem os saberes atitudinais - aqueles que se referem ao modo de ser/estar com as pessoas.

Os resultados, considerando-se as regularidades na constituição dos saberes docentes dos sujeitos de pesquisa, apontam para a importância das experiências durante a adolescência, da família, dos grupos/ambientes sociais, mas, acima de tudo, à centralidade das experiências escolares e dos processos de formação profissional (licenciatura) na constituição dos saberes docentes, destacando-se as marcas positivas produzidas pelos seus professores ao longo da escolarização básica e superior - com destaque às aprendizagens que concernem aos valores interpessoais, como o respeito, o afeto, a humanização das relações pedagógicas.

Ainda que reconheçam as limitações dos processos formativos profissionais para prepará-los para a docência, exaltam os bons exemplos de professores que tiveram para constituírem a sua própria professoralidade (Nóvoa, 1995a). Bons professores não só da licenciatura, mas também da educação básica, entendidos como aqueles que não se posicionaram distantes dos alunos ou alheios aos seus interesses e expectativas, aqueles que mostraram respeito, que deram atenção, que manifestaram confiança nos alunos. No amálgama de saberes (Tardif, 2012) oriundo de diversas instâncias que constitui os saberes docentes, destaca-se neste estudo a importância daqueles provenientes da experiência (saberes experienciais).

Apresentamos, agora, algumas respostas à segunda questão abordada na pesquisa: como os professores de Biologia mobilizam seus saberes docentes na prática pedagógica? Estes professores mobilizam saberes pedagógicos a partir da experiência construída na prática docente, para dar conta de duas grandes atribuições docentes (Tardif, 2000, 2012; Gauthier et al., 1998), a gestão da classe e a gestão da matéria. Também mobilizam saberes em função da opção própria, do gosto e da realização profissional na docência. Os percursos de mobilização de saberes são muito particularizados e singulares em virtude do estágio em que cada professor se encontra na carreira. Nesse sentido, verificou-se que a professora experiente parece mobilizar saberes mais especificamente na gestão da classe, ao passo que o professor novato o faz na gestão da matéria, ratificando o entendimento de que os saberes docentes são situados no tempo (Tardif, 2012).

No entanto, percebemos também regularidades, dentre as quais podemos destacar a centralidade da mobilização de saberes disciplinares, especialmente, os conceituais, em detrimento aos saberes curriculares e pedagógicos. A prática destacada dos dois professores sujeitos dessa investigação é marcada pelo gosto de exercer a docência, por um profundo carinho pelos alunos, pela importância que atribuem ao "ser professor", pela responsabilidade com que assumem a condução da sala de aula. Ficou evidente, também, a importância dos saberes da ação pedagógica, ou seja, a experiência, o dia a dia desses professores destacados é essencial na apreensão e na mobilização de saberes que lhes dão o referido status no ensino de Biologia. Compreende-se isso, pois ambos os professores enfatizam o valor dos saberes experienciais para dar conta das demandas que envolvem a sala de aula, evidenciando os saberes construídos no cotidiano escolar. 
Assim, a prática vivenciada no dia a dia da docência tanto os auxilia na constituição de saberes, quanto favorece a significação dos saberes pedagógicos visitados na licenciatura que, ao serem mobilizados na complexidade da sala de aula, ganham novos sentidos.

Em síntese, cabe destacar que os sujeitos da pesquisa se constituem de saberes diversos e diferentes e, ao mesmo tempo, mobilizam diferentes e diversos saberes para garantir o seu lugar, a sua condição, o seu fazer em sala de aula. Na dinâmica ou no contexto em que atuam, tais saberes revelam-se como os mais acertados para garantirem uma prática destacada a estes professores de Biologia, bem como, para darem sentido ao seu eu pessoal e profissional, sustentando a realização na docência. Diante dos aspectos lacunares apontados pelos sujeitos de pesquisa no que diz respeito aos processos de formação inicial e continuada e à inexistência de momentos de reflexão sobre/na prática no ambiente escolar, a reflexão sistematizada dos saberes docentes é um dos caminhos para a formação do professor, especialmente aqui tratando, do professor de Biologia. E essa era uma hipótese que nos acompanhava desde o início deste trabalho. É preciso investir em processos de formação inicial e continuada que objetivem os saberes dos professores, a partir da racionalização sobre eles, da valorização deles, garantindo que mais professores destaquem a sua prática - qualificando o ensino e a aprendizagem da Biologia escolar.

As perguntas que elegemos para dar conta dos objetivos da pesquisa não comportam respostas diretas e definitivas, uma vez que os saberes em geral e os saberes docentes, em especial, se constituem, desconstituem e reconstituem num processo interminável em que estão implicadas suas relações sociais, familiares, suas vivências formativas, enfim, conforme ensina Tardif (2000), o saber é constituído nas e pelas experiências sociais. Na visão de Gauthier et al. (1998), até mesmo pela complexidade e subjetivismo do campo investigado, "muitas vezes, esse tipo de pesquisa se limita simplesmente a uma descrição detalhada, específica a um contexto, não se prestando à generalização - próprio de pesquisas qualitativas" (p.166).

Ao concluir uma pesquisa sempre nascem outras perguntas, novas preocupações. Assim, assumimos como desafio para a continuidade e aprofundamento desse estudo, dentre outras possibilidades: a ampliação do grupo-sujeito, incorporando professores que se encontrem em diversas fases da carreira profissional; a inclusão de professores das redes pública e particular, de modo a cotejar a incidência de outros aspectos como condições de trabalho, infraestrutura das escolas, expectativas do corpo discente e familiares etc.; a escuta dos alunos para conhecer a sua visão sobre estes professores que se diferenciam por adotarem práticas qualificadas no ensino de Biologia; o reconhecimento mais detido das concepções dos professores sobre os momentos formativos de estágio, uma vez que vários autores têm apontado a iniciação profissional como uma etapa crucial e, muitas vezes, limitante, da formação docente e da objetivação de saberes. 


\section{Referências}

Acosta, J. M. (2013). O currículo interpretado: o que as escolas, os professores e as professoras ensinam? In J. G. Sacristán, Saberes e incertezas sobre o currículo (pp.188208). Porto Alegre, RS: Penso.

Alves-Mazzotti, A. J., \& Gewandsznadjer, F. (1998). O método nas ciências naturais e sociais: pesquisa quantitativa e qualitativa. São Paulo, SP: Pioneira.

Bardin, L. (2011). Análise de conteúdo. São Paulo, SP: Edições 70.

Borges, C. M. F. (2004). O professor da educação básica e seus saberes profissionais. Araraquara, SP: JM.

Cunha, M. I. da. (2011). O bom professor e sua prática. São Paulo: Papirus.

Ferreira, A. de M., Guimarães, V. S., \& Souza, R. C. C. R. de. (2011). Diretrizes curriculares para cursos de Biologia - a licenciatura sob a égide do mercado. Anais do $8^{\circ}$ Congresso de Pesquisa, Ensino e Extensão PROEC e 63ª Reunião Anual da SBPC. Goiânia, 2011. Disponível em http://www.sbpcnet.org.br/.pdf

Gauthier, C., Martineau, S., Malo, A., \& Simard, D. (1998). Por uma teoria da pedagogia: pesquisas contemporâneas sobre o saber docente. Ijuí: Unijuí.

Huberman, M. (2007). O ciclo de vida profissional dos professores. In A. Nóvoa. Vidas de professores (2a ed.). (pp.31-62). Portugal: Porto.

Marandino, M., Selles, S. E., \& Ferreira, M. S. (2009). Ensino de Biologia: histórias e práticas em diferentes espaços educativos. (Coleção Docência em Formação. Série Ensino Médio). São Paulo: Cortez.

Martins, M. M. M. de C., \& Leite, R. C. M. (2013). Aulas práticas e experimentos no ensino de ciências na escola básica: as contribuições de Derek Hodson. In C. C. B. Carneiro, \& R. C. M. Leite. Ensino de ciências: abordagens múltiplas. (pp. 31-43). Curitiba, PR: CRV. Minayo, M. C. de S. (2010). O desafio da pesquisa social. In M. C. de S. Minayo, S. F. Deslandes, O. Cruz Neto, \& R. Gomes. Pesquisa social: teoria, método e criatividade. (pp. 9-29). Petrópolis, RJ: Vozes.

Nóvoa, A. (1995a). Formação de professores e profissão docente. In A. Nóvoa. Os professores e a sua formação. (pp. 15-34). Portugal: Dom Quixote.

Nóvoa, A. (1995b). O passado e o presente dos professores. In A. Nóvoa, Profissão professor (2a ed.). (pp.13-34). Portugal: Porto.

Nóvoa, A. (2007). Os professores e as histórias de suas vidas. In: A. Nóvoa, Vidas de professores. (2a ed.). (pp.11-30). Portugal: Porto.

Perrenoud, P. (2001). Ensinar: agir na urgência, decidir na incerteza. (2a ed.). Porto Alegre, RS: Artmed. 
Perrenoud, P. (2002). A prática reflexiva no ofício de professor: profissionalização e razão pedagógica. Porto Alegre: Artmed.

Perrenoud, P. (2013). Desenvolver competências ou ensinar saberes? A escola que prepara para a vida. Porto Alegre: Penso.

Pimenta, S. G. (2012). Formação de professores: identidade e saberes da docência. In S. G. Pimenta. Saberes pedagógicos e atividade docente (8a ed.). (pp.15-38). São Paulo, SP: Cortez.

Schön, D. (1995a). Formar professores como profissionais reflexivos. In A. Nóvoa. Os professores e a sua formação. (pp. 79-91). Portugal: Dom Quixote.

Schön, D. (2000). Educando o profissional reflexivo: um novo design para o ensino e a aprendizagem. Porto Alegre: Artmed.

Tardif, M. (2000). Saberes profissionais dos professores universitários: elementos para uma epistemologia da prática profissional dos professores e suas consequências em relação à formação para o magistério. Revista Brasileira de Educação, 13, 5-24.

Tardif, M. (2012). Saberes docentes e formação profissional. (14a ed.). Petrópolis: Vozes.

Renata Confortin

http://orcid.org/0000-0003-2079-2095

Universidade de Passo Fundo (UPF)

Faculdade de Educação (FAED)

Passo Fundo, Brasil

confortinrenata@gmail.com

Flávia Eloisa Caimi

http://orcid.org/0000-0001-5509-6060

Universidade de Passo Fundo (UPF)

Faculdade de Educação (FAED)

Passo Fundo, Brasil

caimi.flavia@gmail.com

Submetido em 20 de Novembro 2015

Aceito em 2 de Março 2017

Publicado em 30 de Abril de 2017 